\title{
Directed evolution of amidase in Methylophilus methylotrophus; purification and properties of amidases from wild-type and mutant strains
}

\author{
Nigel J. Silman, ${ }^{1}$ Mark A. Carver ${ }^{2}$ and Colin W. Jones ${ }^{1 *}$ \\ ${ }^{1}$ Department of Biochemistry, University of Leicester, Leicester LE1 7RH, UK \\ ${ }^{2}$ ICI Biological Products, Billingham, Cleveland TS23 ILB, UK
}

(Received 19 July 1990; revised 26 September 1990; accepted 3 October 1990)

\begin{abstract}
The obligately methylotrophic bacterium Methylophilus methylotrophus hydrolyses acetamide and acrylamide using a cytoplasmic amidase. In previous work, continuous culture was used to isolate spontaneous mutants which overexpressed either the wild-type amidase (strain MM6) or a mutant amidase with an apparently higher $K_{\text {cat }}$ (strain MM8). We now report that NTG mutagenesis of strain MM8 followed by acrylamide-limited growth at low dilution rate $\left(D 0.025 \mathrm{~h}^{-1} ; 37^{\circ} \mathrm{C}\right)$ led to the selection of a strain which continued to overexpress the amidase, but which exhibited an unexpectedly low amidase activity and a greatly decreased $K_{\mathrm{m}}$ for acrylamide (strain MM15). Amidases from the wild-type and mutant strains were purified and shown to be homotetramers (subunit $M_{\mathrm{r}} 38000$, pI 4.1). The $\mathrm{N}$-terminal amino acid sequence of the wild-type enzyme was $90 \%$ homologous with the aliphatic amidase from Pseudomonas aeruginosa, and Southern blotting using an oligonucleotide probe for this region showed that overexpression of the enzyme in the mutant strains was not due to gene amplification. Compared with the wild-type and MM6 enzymes, the MM8 enzyme exhibited a threefold higher $K_{\text {cat }}$ and a slightly lower $K_{\mathrm{m}}$ for acrylamide, whereas the MM15 enzyme exhibited a similar $K_{\text {cat }}$ and an eightfold lower $K_{\mathrm{m}}$ for acrylamide. The MM15 enzyme also reacted more extensively with the thiol group reagent DTNB, had a significantly lower sedimentation coefficient and exhibited a more relaxed substrate specificity, all of which were compatible with a looser tetrameric structure. It was also much more susceptible than the other three enzymes to inactivation by high temperature or by freezing and thawing (MM15 $\gg$ MM8 $>$ MM6/wild-type), both of which variably dissociated the enzyme into inactive dimers and monomers. The amidase activity of strain MM15 was almost 15-fold higher following growth at $25^{\circ} \mathrm{C}$ than at $37^{\circ} \mathrm{C}$, since at this lower temperature the enzyme exhibited a similar $K_{\text {cat }}$ to the MM8 enzyme and was not significantly dissociated. However, as strain MM15 readily outgrew the organism from which it was derived (strain MM8) during acrylamide-limited continuous culture at $37^{\circ} \mathrm{C}$, it is clear that under these conditions a low $K_{\mathrm{m}}$ was a greater selective advantage than a high $K_{\text {cat }}$.
\end{abstract}

\section{Introduction}

Methylophilus methylotrophus, a methylotrophic bacterium of commercial importance (see Vasey \& Powell, 1984; Large \& Bamforth, 1988), grows only on carbon sources such as methanol, methylamine and trimethylamine that contain no carbon-carbon bonds (Anthony, 1982). It also uses a very restricted range of nitrogen sources including ammonia, urea, methylamine, trimethylamine and aliphatic amides, all of which are initially converted to ammonia which is then assimilated using the glutamine synthetase/glutamate synthase (glutamine

Abbreviations: DTNB, 5,5'-dithiobis-(2-nitrobenzoic acid); NTG, $N$ methyl- $N^{\prime}$-nitro- $N$-nitrosoguanidine; TNB, 5-thio-2-nitrobenzoic acid.

0001-6394 (C) 1991 SGM synthetase/glutamine-oxoglutarate aminotransferase; GS/GOGAT) system (Windass et al., 1980).

The hydrolysis of aliphatic amides to ammonia and the corresponding acid by $\boldsymbol{M}$. methylotrophus is catalysed by a cytoplasmic amidase, the physiological regulation of which has been examined in detail (Silman et al., 1989). The enzyme is induced by various short-chain amides, and repressed by ammonia but not by organic acids or methanol. It therefore differs from the extensively investigated aliphatic amidases of Pseudomonas aeruginosa and Brevibacterium sp. R312, both of which are induced by short-chain amides, and repressed by organic acids but not ammonia (Clarke, 1970, 1984; Maestracci et al., 1984, 1988). As short-chain amides probably enter bacteria by simple diffusion, amidase is the first enzyme of amide metabolism. 
Previous work from this laboratory has shown that the amidase of $M$. methylotrophus undergoes the expected phenotypic response of such a first enzyme, being maximally expressed during growth under amide limitation. It also readily undergoes genotypic changes, and growth for even a relatively short period of time (as little as 10 generations) at low dilution rate in acetamide- or acrylamide-limited continuous culture led to the spontaneous appearance of hyperactive strains (Silman et al., 1989). This approach enabled the isolation of two mutant strains of $M$. methylotrophus (strains MM6 and MM8), the amidase activities of which were respectively 4 and 12 times that of the wild-type organism. However, as both of the mutant strains contained approximately four times as much amidase as the wild-type organism, it was concluded that the catalytic activity $\left(K_{\text {cat }}\right)$ of the MM8 enzyme was approximately three times higher than that of the wild-type and MM6 enzymes.

The appearance of these two hyperactive strains during growth under amide limitation was probably due to the selection of spontaneous mutants which exhibited enhanced specific growth rates $(\mu)$ at low amide concentrations and therefore readily took over the cultures under these strongly selective conditions (Silman et al., 1989), i.e. they exhibited an increased 'biological fitness' (see Dykhuizen et al., 1987). Although both of these strains exhibited an increased cellular amidase activity (increased enzyme concentration and/ or $K_{\text {cat }}$ ), takeover would also have been expected to occur had the mutants alternatively exhibited an increased affinity (decreased $K_{\mathrm{m}}$ ) for the growth-limiting amide, but no spontaneous mutants of this type were observed (although the large increase in the $K_{\text {cat }}$ of the amidase from strain MM8 was accompanied by a small but significant decrease in the $K_{\mathrm{m}}$ ).

We have therefore sought to isolate such a mutant using chemical mutagenesis followed by acrylamidelimited continuous culture. This paper reports the isolation of strain MM15, a mutant which contains an amidase with a low $K_{\mathrm{m}}$ for acrylamide, and describes the purification and properties of amidases from wild-type and mutant strains (MM6, MM8 and MM15) of $\boldsymbol{M}$. methylotrophus.

\section{Methods}

Maintenance of bacterial cultures. Stock cultures of wild-type Methylophilus methylotrophus (NCIB 10515) and strains MM6, MM8 and $\mathrm{MM} 15$ derived from it were stored in $20 \%(\mathrm{v} / \mathrm{v})$ sterile glycerol at $-70^{\circ} \mathrm{C}$ and were routinely maintained on methanol $/ \mathrm{minimal}$ salts (SE II) agar plates (Silman et al., 1989).

Growth. M. methylotrophus was grown in methanol/minimal salts (SE II) medium at $37^{\circ} \mathrm{C}$ in batch, fed-batch and continuous culture with ammonia, acetamide or acrylamide as the source of nitrogen (Silman $e t$ al., 1989). Growth was measured from the increase in optical density at $600 \mathrm{~nm}$, and cell density (mg dry weight $\mathrm{ml}^{-1}$ ) was calculated by multiplying $\mathrm{OD}_{600}$ by 0.53 .

Mutagenesis with NTG. M. methylotrophus strain MM8 was grown overnight in batch culture on a methanol/acetamide/minimal salts medium, then harvested and resuspended to a cell density of $0.6 \mathrm{mg}$ dry wt $\mathrm{ml}^{-1}$ in $0.1 \mathrm{M}$-citric acid $/ 0.1 \mathrm{M}$-trisodium citrate buffer $\mathrm{pH} 5.5$, containing $100 \mu \mathrm{g} \mathrm{NTG} \mathrm{ml} \mathrm{m}^{-1}$. The cells were incubated at $37^{\circ} \mathrm{C}$ for $15 \mathrm{~min}$ prior to reharvesting. The cell pellet was then washed, resuspended in sterile growth medium and grown overnight at $37^{\circ} \mathrm{C}$ in batch culture.

Harvesting and preparation of washed or broken cells for measurement of amidase activity. Cells (approximately $20 \mathrm{mg}$ ) were harvested by centrifugation, then washed and resuspended in $0 \cdot 1 \mathrm{M}$-citric acid $/ 0.2 \mathrm{M}$ $\mathrm{Na}_{2} \mathrm{HPO}_{4}$ buffer $\mathrm{pH} 6.0$ to a cell density of approximately $5 \mathrm{mg} \mathrm{m}^{-1}$ and, if required, disrupted by sonication (Silman et al., 1989).

Purification of wild-type and mutant amidases. Harvested cells were washed and resuspended in $20 \mathrm{~mm}$-Bis-Tris buffer $\mathrm{pH} 6.8$ to a cell density of 40-50 $\mathrm{mg}$ dry $\mathrm{wt} \mathrm{ml}^{-1}$, then disrupted by passage three times through an Aminco French pressure cell at 15000 p.s.i. (103.5 MPa). The broken cells were centrifuged at $18000 \mathrm{~g}$ for $30 \mathrm{~min}\left(4^{\circ} \mathrm{C}\right)$ to yield a cell-free extract which was finally centrifuged at $175000 \mathrm{~g}$ for $75 \mathrm{~min}$ to produce a high-speed supernatant essentially free of particulate material. The high-speed supernatant $\left(50 \mathrm{ml} ; 20 \mathrm{mg} \mathrm{ml}^{-1}\right)$ was passed through an acrodisc filter $(0.2 \mu \mathrm{m}$ pore size; Gelman $)$, then loaded on to an FPLC Mono-Q anion-exchange column (Pharmacia) equilibrated with $20 \mathrm{~mm}$-Bis-Tris buffer $\mathrm{pH} 6.8$ and eluted using a linear gradient of $\mathrm{KCl}$ ( 0 to $350 \mathrm{mM}$ over $20 \mathrm{~min}$ ) at a flow rate of $4 \mathrm{ml} \mathrm{min}^{-1}$. Amidase eluted from the column at $280-300 \mathrm{mM}-\mathrm{KCl}$ and was judged by SDSPAGE and scanning densitometry to be approximately $95 \%$ pure. Further purification was achieved by loading the peak fraction $(10 \mathrm{ml}$; $5 \mathrm{mg} \mathrm{ml}^{-1}$ ) on to an FPLC Superose- 6 gel-filtration column equilibrated with $20 \mathrm{~mm}$-Bis-Tris buffer $\mathrm{pH} 6.8$ containing $100 \mathrm{mM}-\mathrm{KCl}$, and then eluting with the same buffer at a flow rate of $0.3 \mathrm{ml} \mathrm{min}^{-1}$. The amidase was judged by SDS-PAGE to be pure after this step and was stored at $-20^{\circ} \mathrm{C}\left(4^{\circ} \mathrm{C}\right.$ for the MM15 enzyme) until required.

Measurement of enzyme activities. Amidase activities were determined by measuring the rate of ammonia formation at pH 6.0 (Silman et al., 1989). $K_{\mathrm{m}}$ values for acetamide and acrylamide were determined from plots of $s / v$ versus $s$ using substrate concentrations in the range 0.1-100 mM (Silman et al., 1989). Glutamate synthase activity was measured from the rate of oxidation of NADH in the presence of glutamine and 2-oxoglutarate (Silman et al., 1989). Protein was measured using the method of Lowry.

Inhibition of amidase activity by DTNB. Purified amidase $(0.5 \mathrm{mg})$ was incubated with $2 \mathrm{~mm}$-DTNB in $0.1 \mathrm{M}$-citric acid/0.2 M- $\mathrm{Na}_{2} \mathrm{HPO}_{4}$ buffer $\mathrm{pH} 8.0$ at $26^{\circ} \mathrm{C}$. Aliquots were withdrawn at suitable intervals and assayed for amidase activity using acetamide as the substrate.

Quantification of cysteine residues in amidase using DTNB. DTNBaccessible cysteine residues were determined by incubating purified amidase $(0.5 \mathrm{mg})$ with $2 \mathrm{mM}$-DTNB/1 mM-EDTA in $0.1 \mathrm{M}$-citric acid/0.2 M- $\mathrm{Na}_{2} \mathrm{HPO}_{4}$ buffer $\mathrm{pH} 8.0$ at $26^{\circ} \mathrm{C}$ to a final volume of $1 \mathrm{ml}$ in a $1 \mathrm{ml}$ cuvette ( $1 \mathrm{~mm}$-EDTA had no effect on the inhibition of amidase activity by DTNB). The release of TNB $^{2-}$ was followed spectrophotometrically at $412 \mathrm{~nm}$ until complete, and the number of cysteine residues (-SH groups) present in the enzyme was calculated using an $\varepsilon$ value of $13.7 \mathrm{~mm}^{-1} \mathrm{~cm}^{-1}$. Total cysteine residues were determined using the same procedure except that SDS $(2 \%, w / v)$ was included in the buffer

Determination of isoelectric point. Isoelectric focussing was carried out using ultrathin $5 \%(\mathrm{w} / \mathrm{v})$ polyacrylamide slab gels containing $2.2 \%$ 
(w/v) ampholytes (pH range 4.0-6.5) on an LKB Multiphor II system. Electrode wicks were used with $0.1 \mathrm{M}-\beta$-alanine (cathode) and $0.1 \mathrm{M}$ glutamic acid/0.5 M-phosphoric acid (anode) as the electrode solutions. The gels were prefocussed for $20 \mathrm{~min}$ at constant power $(15 \mathrm{~W})$, then run under the same conditions for $2 \mathrm{~h}$ before being fixed in $0.8 \mathrm{M}$ trichloroacetic acid for $1 \mathrm{~h}$, washed overnight in distilled water and stained for protein using Kenacid blue $\mathbf{R}$.

Determination of amino acid composition and $N$-terminal sequence. The amino acid composition of the wild-type amidase was measured by $\mathrm{Dr}$ L. Packman (University of Cambridge, UK). The $\mathrm{N}$-terminal amino acid sequence of the enzyme (approximately $1 \mathrm{nmol}$ blotted on to a polyvinylidene difluoride disc) was determined using an Applied Biosystems model $\mathbf{4 7 0}$ gas-phase sequencer.

Polyacrylamide gel electrophoresis. Discontinuous non-dissociating PAGE and SDS-PAGE were carried out as described previously (Silman et al., 1989) using the procedures of Hames (1981). Gels were stained for protein with Kenacid blue R, and non-dissociating gels were also stained for acyl transferase activity using the method of Wyndham \& Slater (1986).

Analytical ultracentrifugation. Sedimentation coefficients $(0.7 \mathrm{mg}$ amidase $\left.\mathrm{ml}^{-1}\right)$ and $M_{\mathrm{r}}$ values $\left(0.4 \mathrm{mg}\right.$ amidase $\left.\mathrm{ml}^{-1}\right)$ were determined by sedimentation velocity and sedimentation equilibrium ultracentrifugation respectively in $20 \mathrm{mM}$-Bis-Tris $\mathrm{pH} 6.8$ at $5^{\circ} \mathrm{C}$ using an MSE Centriscan 75 analytical ultracentrifuge. Sedimentation velocity diagrams of the amidases in four multiplexed cells were recorded at 37000 r.p.m. $\left(113000 \mathrm{~g}\right.$ ) by measuring the $A_{280}$ of the cells at regular intervals. $M_{\mathrm{r}}$ values of the amidases were determined by allowing the enzymes to attain equilibrium by centrifuging at 13000 r.p.m. $(14000 \mathrm{~g})$ for $18 \mathrm{~h}$ in $1.6 \mathrm{~mm}$ columns and then measuring $A_{280}\left(A_{350}\right.$ was also measured in order to provide a base-line and hence minimize any effects of window contamination; Spragg, 1980). Data capture and analysis were effected using an Apple Graphics tablet and microcomputer. Sedimentation coefficients were corrected to standard conditions to give $s_{20 \text {, w }}$ values, and $M_{\mathrm{r}}$ values were computed from the linear regression of $\ln$ (absorbance) versus (radial distance) ${ }^{2}$, all using established procedures and local software (Rowe, 1984).

Preparation and restriction of chromosomal DNA. Chromosomal DNA was prepared from wild-type and mutant strains of $M$. methylotrophus essentially by the method of Chow et al. (1977) except that the lysate was digested overnight with proteinase $\mathrm{K}$ before being extracted three times with phenol/chloroform/isoamyl alcohol $(50: 50: 2$, by vol.) and then precipitated with $100 \%$ ethanol. Samples of the DNA $(15 \mu \mathrm{g})$ were restricted overnight at $37^{\circ} \mathrm{C}$ in a mixture containing $2 \mu \mathrm{l}$ restriction buffer (Maniatis et al., 1982) and $2 \mu \mathrm{l}$ EcoRI, BamHI or HindIII (10 U $\mathrm{ml}^{-1}$ ). The resultant restriction fragments, together with samples of chromosomal DNA, were separated by electrophoresis at $100 \mathrm{~V}$ for $2.5 \mathrm{~h}$ in $1 \%(\mathrm{w} / \mathrm{v})$ agarose.

Synthesis and labelling of an oligonucleotide probe for the amidase structural gene. A 17-mer oligonucleotide probe based on the $\mathrm{N}$ terminal sequence of the amidase was synthesized by standard procedures using an Applied Biosystems 380B synthesizer, and was labelled with ${ }^{32} \mathrm{P}$ at the $5^{\prime}$ end using T4 polynucleotide kinase (Maniatis et al., 1982). Incorporation was monitored by chromatography of a small amount of the probe on DE81 paper with $0.3 \mathrm{M}$-ammonium formate as the solvent, followed by autoradiography of the dried chromatogram.

Southern blotting and hybridization. Southern blotting and hybridization $\left(32^{\circ} \mathrm{C}\right)$ was performed using standard procedures (Maniatis et al., 1982) except that Hybond $N$ membrane was used instead of nitrocellulose during the blotting, and the hybridization buffer contained $0.25 \mathrm{~g}$ Marvel dried milk powder, $3 \mathrm{~g}$ polyethylene glycol $600,1.5 \times$ SSPE buffer $\mathrm{pH} 7.4$ and $1 \%$ SDS in a final volume of $50 \mathrm{ml}$
$(1 \times \mathrm{SSPE}$ is $0.15 \mathrm{M}-\mathrm{NaCl}, 0.01 \mathrm{M}$-sodium phosphate, $0.001 \mathrm{M}$-EDTA) Following hybridization, membranes were washed three times in $3 \times$ SSC buffer containing $1 \% \mathrm{SDS}$, and then three times in $0.5 \times \mathrm{SSC}$ buffer containing $1 \% \operatorname{SDS}$ (all at $\left.32^{\circ} \mathrm{C}\right)(1 \times \mathrm{SSC}$ is $0.15 \mathrm{M}$ $\mathrm{NaCl} / 0.015 \mathrm{M}$-trisodium citrate, $\mathrm{pH} 7 \cdot 0$ ). Washed membranes were wrapped in Saran Wrap and autoradiographed for $48 \mathrm{~h}$ at $-70^{\circ} \mathrm{C}$.

Presentation of results. Where appropriate, results are presented as the mean $\pm \mathrm{SEM}$, with the number of independent determinations in parentheses.

\section{Results}

Selection of a mutant with a low- $K_{\mathrm{m}}$ amidase using NTG mutagenesis followed by growth in continuous culture under acrylamide limitation

M. methylotrophus strain MM8 was mutagenized using NTG and then grown in continuous culture at low dilution rate $\left(0.025 \mathrm{~h}^{-1}\right)$ for approximately 23 generations under acrylamide limitation. Broken cells prepared from the resultant culture (culture $\mathrm{C}$; for definition of cultures A and B see Silman et al., 1989) exhibited a $K_{\mathrm{m}}$ for acrylamide of $2.0 \mathrm{mM}$, a value almost an order of magnitude lower than that of the wild-type organism or strains MM6 and MM8.

Culture $\mathrm{C}$ was streaked on to methanol/acetamide plates and six colonies were subsequently picked off at random and grown in acrylamide-limited fed-batch culture $\left(\mu=0.3 \mathrm{~h}^{-1}\right)$. All of these colonies exhibited a substantially lower $K_{\mathrm{m}}$ for acrylamide, but not for acetamide, than the wild-type organism or strains MM6 and MM8.

Bacteria from one colony, subsequently called strain MM15, were examined in more detail following growth in ammonia- or amide-limited fed-batch and continuous culture (Table 1). The results showed that the MM15 amidase still required an amide for induction, and that its maximum activity following growth in continuous culture was $2 \cdot 1 \mu \mathrm{mol} \mathrm{min}^{-1}(\mathrm{mg} \text { cells) })^{-1}$ (measured with acetamide as substrate). As this was achieved during growth at a dilution rate of $0.05 \mathrm{~h}^{-1}$, the latter was taken to be the optimum dilution rate $\left(D_{\text {opt }}\right)$ for amidase production in strain MM15. This activity was similar to that of the wild-type, but was approximately one-quarter that of strain MM6 and only approximately one-fifteenth that of strain MM8, from which strain MM15 was derived (Silman et al., 1989). The $K_{\mathrm{m}}$ for acetamide $(1.2 \mathrm{mM})$ of strain MM15 was similar to that of the other three organisms, whereas the $K_{\mathrm{m}}$ for acrylamide was much lower (2.0 versus 18.7, 19.4 and $12.3 \mathrm{mM}$ ); neither $K_{\mathrm{m}}$ value was affected by the growth conditions.

SDS-PAGE and scanning densitometry of cellular proteins from $M$. methylotrophus strain MM15 following growth in continuous culture at $D_{\text {opt }}$ under acetamide 
limitation showed that the amidase comprised $23 \%$ of the total cell protein (similar to that of strains MM6 and MM8 grown under the same conditions, and approximately four times that of the wild-type organism). The $K_{\text {cat }}$ of the enzyme for acetamide hydrolysis, calculated from its cellular concentration and specific activity, assuming a native $M_{\mathrm{r}}$ of 155000 , was $22 \mathrm{~s}^{-1}$ (i.e. approximately one-fifth that of the wild-type organism and strain MM6, and one-fifteenth that of strain MM8; Silman et al., 1989).

Purification of the amidase from wild-type $M$. methylotrophus

$M$. methylotrophus was grown in continuous culture under acetamide limitation $\left(D=0.15 \mathrm{~h}^{-1}\right)$. Cells were harvested, sonicated and centrifuged to produce a highspeed supernatant fraction from which the amidase was purified using anion-exchange and gel-filtration FPLC (Table 2; Fig. 1). The 20.5-fold purification that was required to prepare the pure amidase from $M$. methylotrophus indicated that it constituted $4.9 \%$ of the cell protein during acetamide-limited growth, a value very close to the $4.3 \%$ previously reported from analysis of whole-cell polypeptide profiles using SDS-PAGE and scanning densitometry (Silman et al., 1989).

SDS-PAGE showed that the dissociated enzyme consisted of a single protein of $M_{\mathrm{r}} 38000$. Gel-filtration chromatography and sedimentation-equilibrium ultracentrifugation gave $M_{\mathrm{r}}$ values of 155000 and 150000 respectively for the native enzyme, indicating that the enzyme was a homotetramer. The amidase from $\boldsymbol{M}$. methylotrophus therefore contains fewer subunits than the amidases from $P$. aeruginosa $(6 \times 38400)$ and Arthrobacter sp. J1 $(8 \times 40000)$ and is composed of slightly smaller subunits than the amidase from Brevibacterium sp. R312 (4 × 43000) (Asano et al., 1982; Clarke, 1984; Maestracci et al., 1988).

The purified amidase exhibited several kinetic properties which were quantitatively very similar to those previously determined with whole or broken cells of wild-type $M$. methylotrophus (Silman et al., 1989), viz. a $K_{\text {cat }}$ for acetamide and acrylamide of $128 \mathrm{~s}^{-1}$ and $151 \mathrm{~s}^{-1}$ respectively, and a $K_{\mathrm{m}}$ for acetamide and acrylamide of $1 \cdot 1 \mathrm{mM}$ and $16 \cdot 1 \mathrm{mM}$ respectively.

\section{Amino acid composition and $N$-terminal sequence}

Comparison of the amino acid composition of the $M$. methylotrophus and $P$. aeruginosa amidases based on a common chain length of 346 amino acids (subunit $M_{\mathrm{r}}$ 38000) indicated that the $M$. methylotrophus amidase contained substantially more glycine $(+14)$, serine

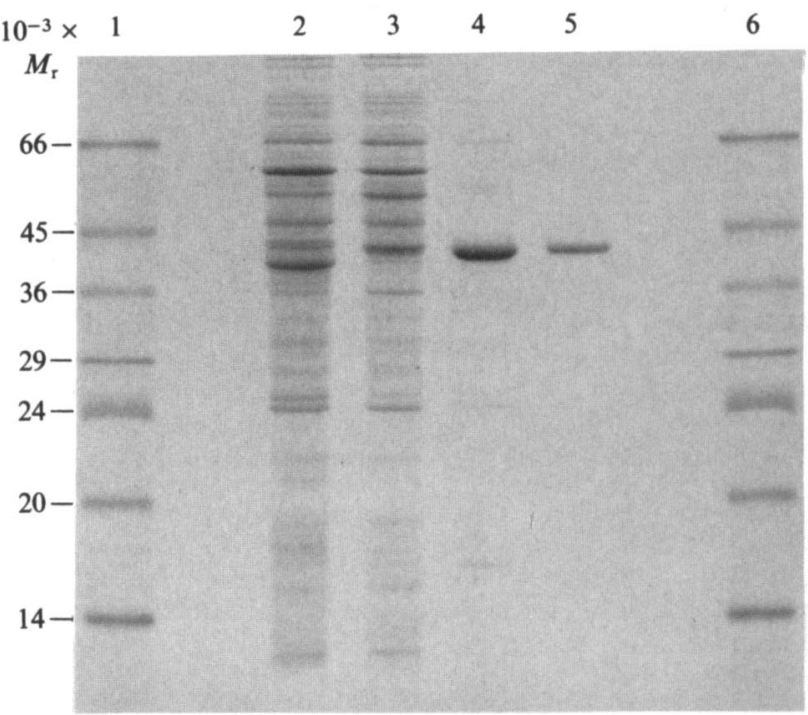

Fig. 1. Purification of amidase from $M$. methylotrophus. Cells were disrupted by sonication, then centrifuged to produce a high-speed supernatant fraction from which amidase was purified using anionexchange (Mono-Q) and gel-filtration (Superose-6) FPLC as described in Methods. Samples were subjected to SDS-PAGE and then stained with Kenacid blue. Tracks 1 and $6, M_{\mathrm{r}}$ standards; 2 , cells; 3, high-speed supernatant ; 4, bulked Mono-Q fractions; 5 , Superose-6 peak fraction.

Table 1. Amidase activities of $M$. methylophilus MM15 grown in fed-batch and continuous culture

$M$. methylotrophus strain MM15 was grown in fed-batch culture $\left(\mu=0.2 \mathrm{~h}^{-1}\right)$ and continuous culture $\left(D=0.05 \mathrm{~h}^{-1}\right)$ in minimal medium supplemented with methanol and various limiting nitrogen sources as described in Methods. Amidase activity was measured with acetamide as substrate.

\begin{tabular}{llc}
\hline $\begin{array}{c}\text { Growth } \\
\text { conditions }\end{array}$ & $\begin{array}{c}\text { Nutrient } \\
\text { limitation }\end{array}$ & $\begin{array}{c}\text { Amidase activity } \\
{\left[\mu \mathrm{mol} \mathrm{min}^{-1}\left(\mathrm{mg} \mathrm{cells}^{-1}\right]\right.}\end{array}$ \\
\hline Fed-batch & Ammonia & 0.64 \\
& Acetamide & 2.14 \\
& Acrylamide & 3.59 \\
Continuous & Acetamide & 2.06 \\
& Acrylamide & 1.51 \\
\hline
\end{tabular}

$(+13)$ and histidine $(+10)$, but substantially less methionine $(-8)$ and arginine $(-10)$, than the $P$. aeruginosa amidase (Table 3 ). The two enzymes contained similar amounts of all the other amino acids $( \pm \leqslant 4)$; the amount of tryptophan was not determined. The calculated numbers of negative/positive charges on the two enzymes at $\mathrm{pH} 7.0$ were $-42 /+35$ and $-45 /+38$ respectively, giving each a net charge of -7 ; the calculated isoionic points for the two enzymes were 6.35 and 6.63 respectively.

$\mathrm{N}$-terminal amino acid sequencing of the $M$. methylotrophus amidase showed that 17 of the first 19 residues 
Table 2. Purification of amidase from wild-type M. methylotrophus

M. methylotrophus was grown in acetamide-limited continuous culture $\left(D=0 \cdot 15 \mathrm{~h}^{-1}\right)$. Washed cells were disrupted by sonication, then centrifuged to produce a high-speed supernatant from which the amidase was purified using anion-exchange (mono-Q) and gel filtration (superose-6) FPLC as described in Methods. Amidase activity was measured at $37^{\circ} \mathrm{C}$ with acetamide as substrate.

\begin{tabular}{lcccrr}
\hline \hline & $\begin{array}{c}\text { Total } \\
\text { protein } \\
(\mathrm{mg})\end{array}$ & $\left.\begin{array}{c}\text { Specific } \\
\text { activity } \\
\left(\mu \mathrm{mol} \mathrm{min}^{-1}\right.\end{array} \mathrm{mg}^{-1}\right)$ & \multicolumn{2}{c}{$\begin{array}{c}\text { Total } \\
\text { activity } \\
\left(\mu \mathrm{mol} \mathrm{min}^{-1}\right)\end{array}$} & \multicolumn{2}{c}{$\begin{array}{c}\text { Yield } \\
(\%)\end{array}$} & $\begin{array}{c}\text { Purifi- } \\
\text { cation }\end{array}$ \\
(-fold $)$
\end{tabular}

Table 3. Comparison of the amino acid composition of amidases from $P$. aeruginosa and $M$. methylotrophus

Amidase from $M$. methylotrophus was purified, and its relative amino acid content determined, as described in Methods. The amino acid composition of the enzyme was calculated on the basis of 346 residues per subunit $M_{\mathrm{r}} 38000$ ) as reported for the $P$. aeruginosa amidase, the actual and derived amino acid sequence of which has been published (Ambler et al., 1987; Brammar et al., 1987). As the tryptophan content was not determined, the number of tryptophan residues was assumed to be 6 by analogy with the $P$. aeruginosa enzyme. Similarly as no distinction was made in the analysis between aspartate/asparagine and glutamate/glutamine, the ratios were also assumed to be the same as for the $P$. aeruginosa enzyme.

\begin{tabular}{lccc}
\hline \hline & \multicolumn{2}{c}{ No. of residues } & \\
\cline { 2 - 3 } Amino acid & M. met. & P. aer. & Difference \\
\hline Gly & 48 & 34 & +14 \\
Ala & 29 & 32 & -3 \\
Val & 19 & 23 & -4 \\
Leu & 17 & 20 & -3 \\
Ile & 18 & 21 & -3 \\
Ser & 29 & 16 & +13 \\
Thr & 17 & 13 & +4 \\
Asp + Asn & $28(17+11)$ & $32(19+13)$ & -4 \\
Glu + Gln & $39(25+14)$ & $41(26+15)$ & -2 \\
Phe & 11 & 9 & +2 \\
Tyr & 15 & 17 & -2 \\
Trp & $(6)$ & 6 & 0 \\
Cys & 7 & 9 & -2 \\
Met & 7 & 15 & -8 \\
Pro & 13 & 17 & -4 \\
Lys & 17 & 15 & +2 \\
His & 17 & 7 & +10 \\
Arg & 9 & 19 & -10 \\
& No. of charges $(\mathrm{pH} 7 \cdot 0)$ & \\
Asp $(-1 \cdot 0)$ & -17 & -19 & +2 \\
Glu $(-1 \cdot 0)$ & -25 & -26 & +1 \\
His $(+0 \cdot 5)$ & +9 & +4 & +5 \\
Lys $(+1 \cdot 0)$ & +17 & +15 & +2 \\
Arg $(+1 \cdot 0)$ & +9 & +19 & 0 \\
Total & -7 & -7 & \\
\hline \hline
\end{tabular}

were identical to those of the $P$. aeruginosa amidase (Ambler et al., 1987; Brammar et al., 1987):

1

10

19

M.met. M I H(G)D I S S S Q D T V G V A V V (N)

P.aer. MRH G D I S S NDT VGVAVV N

The only differences were the replacement of arginine by isoleucine at position 2 and the conservative replacement of glutamine by asparagine at position 10 .

\section{Southern blotting}

The possibility that the approximately fourfold higher amidase concentration in strains MM6, MM8 and MM15 than in the wild-type organism was due to gene amplification was investigated using Southern blotting. A sequence of six amino acids at the $\mathrm{N}$-terminal end of the amidase (MIHGDI-) was identified as being suitable for the synthesis of an oligonucleotide probe. A mixture of 17-mers (ATG AT[ACT] CA[CT] GG[ACTG] $\mathrm{GA}[\mathrm{CT}] \mathrm{AT}$; 48 redundancies) was therefore synthesized and labelled with ${ }^{32} \mathrm{P}$. DNA was prepared from the wild-type and mutant strains, digested with restriction endonucleases (BamHI, HindIII and EcoRI) and subjected to Southern blotting using the ${ }^{32} \mathrm{P}$-labelled probe. The resultant autoradiographs showed that the major hybridizing fragment in each digest $(12.1 \mathrm{~kb}, 12.8 \mathrm{~kb}$ and $8.6 \mathrm{~kb}$ respectively) was present at approximately the same intensity in the wild-type and mutant strains, indicating that no significant amplification of the amidase gene had occurred.

Comparison of kinetic properties of wild-type and mutant amidases

Amidases were purified from the three mutant strains of M. methylotrophus (MM6, MM8 and MM15) using the method described above for the wild-type enzyme, and their kinetic properties were compared (Table 4). The purification factors for the wild-type, MM6 and MM8 enzymes were essentially as predicted from their cellular concentrations (see above; also Silman et al., 1989) on the assumption that the purification factor should be equal to 100 divided by the amidase concentration expressed as a percentage of the total cell protein. In contrast, the purification factor for the MM15 enzyme was approximately five times the predicted value. More detailed analysis of this purification showed that approximately four-fifths of the total amidase was in the form of an inactive enzyme which ran slightly ahead of the active enzyme during anion-exchange FPLC. As the inactive form was discarded during the purification procedure, the resultant purification factor was consider- 
ably higher than predicted from the measured concentration of amidase within the cell.

As expected from the above results, the $K_{\text {cat }}$ values of the purified wild-type, MM6 and MM8 enzymes (128, 100 and $310 \mathrm{~s}^{-1}$ respectively) were very similar to those calculated from the specific activities of whole or broken cells $\left(96,96\right.$ and $323 \mathrm{~s}^{-1}$ respectively; see also Silman et al., 1989). In contrast, the $K_{\text {cat }}$ value of the pure MM15 enzyme was almost five times higher than that calculated for whole or broken cells ( 96 versus $22 \mathrm{~s}^{-1}$ ). This $K_{\text {cat }}$ value was therefore similar to that of the purified wild-type and MM6 enzymes, but only one-third that of the purified MM8 enzyme; $K_{\text {cat }}$ values of the purified enzymes were therefore in the order wild-type/ MM6/MM15 «MM8 (Table 4). The $K_{\mathrm{m}}$ values of all four purified enzymes for acetamide were similar to the values obtained with broken cells and indicated that the $K_{\mathrm{m}}$ values for acetamide were essentially unchanged in all four strains. In contrast, the $K_{\mathrm{m}}$ values of all four purified enzymes occasionally showed slight differences from those obtained with broken cells, but taken overall were in the order MM15«MM8 < wild-type/MM6.

Comparison of structural and physico-chemical properties of wild-type and mutant amidases

The amidases purified from strains MM6, MM8 and MM15 exhibited a subunit $M_{\mathrm{r}}$ of $38000-40000$ (measured using SDS-PAGE and sedimentation-equilibrium ultracentrifugation respectively) and a native $M_{\mathrm{r}}$ of 150000-155000 (measured using sedimentationequilibrium ultracentrifugation and gel-filtration chromatography respectively), and were therefore structurally similar to the wild-type enzyme. The inactive form of the MM15 enzyme also exhibited a subunit $M_{\mathrm{r}}$ of approximately 38000 as determined by SDS-PAGE, but gel-filtration FPLC showed that the native enzyme was composed of an approximately $3: 1$ mixture of monomers $\left(M_{\mathrm{r}} 38000\right)$ and dimers $\left(M_{\mathrm{r}} 76000\right)$.

Isoelectric focussing of the wild-type, MM6, MM8 and MM15 amidases yielded an isoelectric point (pI) of $4 \cdot 1 \pm 0 \cdot 1$ for all four enzymes. In contrast, the monomeric form of the MM1 5 enzyme exhibited a pI of $5 \cdot 0$, a value commensurate with its elution ahead of the native enzyme during anion-exchange FPLC.

Investigations of the thermostabilities of the wild-type and mutant amidases (Fig. 2) showed that the wild-type and MM6 enzymes were relatively stable at $60{ }^{\circ} \mathrm{C}\left(t_{1 / 2} 3 \cdot 2\right.$ and $4.3 \mathrm{~h}$ respectively), whereas the MM8 enzyme was significantly less stable $\left(t_{1 / 2} \quad 1.5 \mathrm{~h}\right)$ and the MM15 enzyme was much less stable $\left(t_{1 / 2} 0.6 \mathrm{~h}\right)$. Similar relative differences were obtained when the enzymes were incubated at $50^{\circ} \mathrm{C}, 70^{\circ} \mathrm{C}$ and $80^{\circ} \mathrm{C}$, indicating that at all

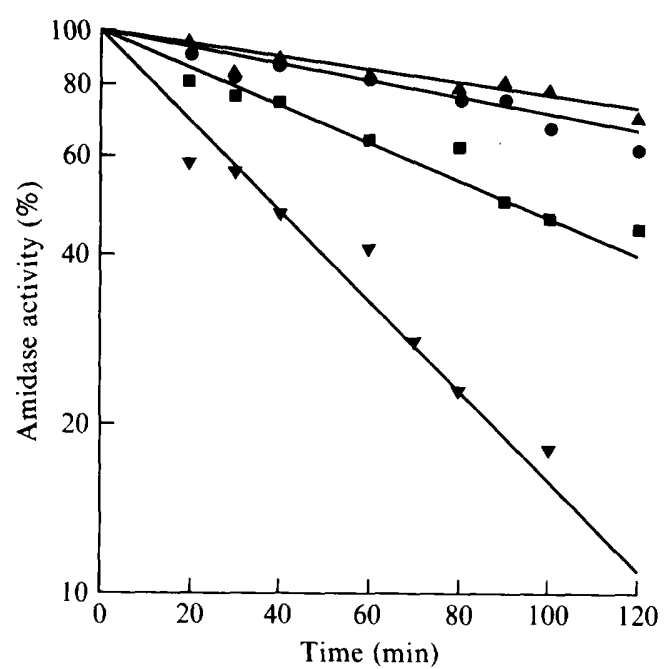

Fig. 2. Thermostability of amidases from $M$. methylotrophus. Wild-type and mutant amidases were purified as described in Methods and then incubated at $60{ }^{\circ} \mathrm{C}$ at a concentration of $0.2 \mathrm{mg} \mathrm{ml}^{-1}$. Samples were removed at intervals and immediately assayed for amidase activity at $37^{\circ} \mathrm{C}$ with acetamide as substrate. Amidase activities of purified wildtype, MM6, MM8 and MM15 enzymes prior to heat treatment were $38.75,35.92,111.00$ and $37.17 \mu \mathrm{mol} \mathrm{min}^{-1}$ (mg protein) $)^{-1}$ respectively. ○, Wild-type; $\Delta$, MM6;, MM8; $\boldsymbol{\nabla}$, MM15.

Table 4. Purification and properties of amidases purified from wild-type and mutant strains of $M$. methylotrophus

Wild-type (WT) and mutant strains of $M$. methylotrophus were grown in continuous culture at $D_{\mathrm{opt}}$ under either acetamide limitation (wild-type and strain MM6) or acrylamide limitation (strains MM8 and MM15). Whole-cell amidase concentrations were measured using SDS-PAGE and scanning densitometry (see Silman et al., 1989). Amidase was purified and assayed as described in Methods; the two purification factors shown are the measured value and, in parentheses, the predicted value based on the measured enzyme concentration in whole cells (100/amidase concentration as percentage of cell protein).

\begin{tabular}{|c|c|c|c|c|c|c|}
\hline \multirow[b]{3}{*}{ Strain } & \multirow{3}{*}{$\begin{array}{c}\text { Concn } \\
\text { of amidase } \\
\text { in cells } \\
(\% \text { of cell protein })\end{array}$} & \multirow[b]{3}{*}{$\begin{array}{l}\text { Purification } \\
\text { factor }\end{array}$} & \multicolumn{4}{|c|}{$\begin{array}{l}\text { Kinetic properties } \\
\text { of pure amidase }\end{array}$} \\
\hline & & & \multicolumn{2}{|c|}{ Acetamide } & \multicolumn{2}{|c|}{ Acrylamide } \\
\hline & & & $\begin{array}{r}K_{\text {cat }} \\
\left(\mathbf{s}^{-1}\right)\end{array}$ & $\begin{array}{c}K_{\mathrm{m}} \\
(\mathrm{mM})\end{array}$ & $\begin{array}{l}K_{\text {cat }} \\
\left(\mathrm{s}^{-1}\right)\end{array}$ & $\begin{array}{c}K_{\mathrm{m}} \\
(\mathrm{mM})\end{array}$ \\
\hline WT & $4 \cdot 3$ & $20.5(23 \cdot 3)$ & 128 & $1 \cdot 1$ & 151 & $16 \cdot 1$ \\
\hline MM6 & $19 \cdot 8$ & $4 \cdot 5 \quad(5 \cdot 1)$ & 100 & $1 \cdot 2$ & 131 & $19 \cdot 0$ \\
\hline MM8 & $24 \cdot 6$ & $4 \cdot 1 \quad(4 \cdot 1)$ & 310 & $1 \cdot 7$ & 419 & $12 \cdot 1$ \\
\hline MM15 & $23 \cdot 0$ & $21.2 \quad(4 \cdot 3)$ & 96 & $1 \cdot 3$ & 127 & $2 \cdot 1$ \\
\hline
\end{tabular}

of these temperatures the thermostabilities of the enzymes were in the order MM15 type/MM6. Similarly, a single freeze-thaw cycle inhibited the wild-type, MM6 and MM8 enzymes by $<1 \%$ compared with $85 \%$ for the MM15 enzyme. 
When samples of the wild-type and mutant enzymes that had been incubated for various periods of time at high temperatures were analysed using gel-filtration FPLC, it was found that they had variably dissociated into dimers and monomers. The propensity of the enzymes to dissociate under these conditions was in the order MM15 $\gg$ MM8 > MM6/wild-type and thus paralleled their loss of amidase activity. Subsequent measurements of the amidase activities of heat-treated samples indicated that the loss of amidase activity was linearly related to the loss of tetrameric structure (Fig. 3). This was confirmed by purifying the dimeric and monomeric forms of the enzymes using gel-filtration FPLC and showing that neither form exhibited any amidase activity.

\section{Effect of the thiol reagent DTNB}

Exposure of the wild-type and mutant amidases to the thiol reagent DTNB $(10: 1$ molar ratio of DTNB to cysteine residues; see Table 3) caused $15-18 \%$ inhibition of the wild-type, MM6 and MM8 amidase activities compared with $35 \%$ inhibition of the MM15 activity (Table 5). Spectrophotometric analysis of the reaction between DTNB and each of these enzymes indicated that the DTNB reacted with 4 cysteine residues in the wild-type, MM6 and MM8 enzymes, and with 8 cysteine residues in the MM15 enzyme. These values increased to $28 \pm 2$ for all four enzymes following exposure to SDS, thus confirming the cysteine content determined by amino acid analysis of the wild-type enzyme ( 7 cysteines per subunit; 4 subunits) and indicating that the mutations had not affected any of the cysteine residues. These results therefore showed that DTNB reacted with $13-15 \%$ of the total cysteine residues in the wild-type, MM6 and MM8 enzymes compared with approximately $31 \%$ in the MM15 enzyme.

The approximately doubled sensitivity and accessibility of the MM15 amidase to DTNB, together with its greater propensity to dissociate at high temperature or by freezing and thawing, suggested that this enzyme has a slightly more open structure than the other amidases. This possibility was investigated by subjecting all four enzymes to sedimentation-velocity ultracentrifugation. The MM15 enzyme sedimented significantly more slowly than the wild-type, MM6 and MM8 enzymes (sedimentation coefficient $5.26 \mathrm{~S}$ versus $6.63,6.81$ and $6.75 \mathrm{~S}$ respectively), thus confirming its less compact structure. The MM15 amidase also exhibited a more relaxed substrate specificity than the other three enzymes, as evidenced by its increased capacity to hydrolyse the longer-chain amides propionamide and butyramide $(949 \%$ and $16 \%$ respectively of the rate with

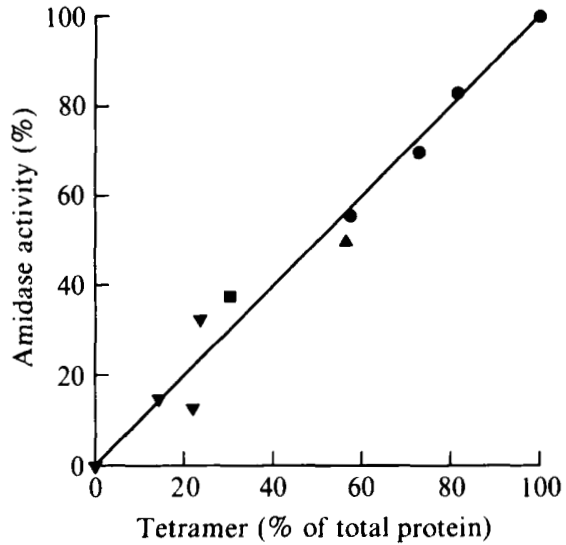

Fig. 3. Relationship between activity and structural integrity of amidases from wild-type and mutant strains of $M$. methylotrophus. Amidases were purified as described in Methods and then incubated at $60{ }^{\circ} \mathrm{C}$ or $70^{\circ} \mathrm{C}$ for up to $3 \mathrm{~h}$. Samples were then assayed for amidase activity with acetamide as substrate, and analysed for loss of tetrameric structure using gel-filtration (Superose-6) FPLC (see legend to Fig. 2 and text). Amidase activities of purified wild-type, MM6, MM8 and MM15 enzymes prior to heat treatment were $38.75,35.92,111.00$ and $37.17 \mu \mathrm{mol} \mathrm{min}^{-1}$ (mg protein) $)^{-1}$ respectively. $\boldsymbol{O}$, Wild-type; $\mathbf{\Delta}$, MM6;, MM8; $\mathbf{\nabla}$, MM15.

Table 5. Sensitivity to DTNB of amidases purified from wild-type and mutant strains of $M$. methylotrophus

The inhibition of amidase activity by DTNB, and the reaction of DTNB with cysteine residues present in the enzyme ( \pm SDS), were determined as described in Methods. Amidase activity was measured with acetamide as substrate. DTNB was present at 10 times the molar concentration of the cysteine residues. The results are the means of up to four independent determinations, each of which did not vary by more than approximately $\pm 10 \%$ of the mean value.

\begin{tabular}{|c|c|c|c|c|c|}
\hline \multirow[b]{2}{*}{ Source } & \multirow{2}{*}{$\begin{array}{l}\text { Enzyme } \\
\text { form }\end{array}$} & \multirow{2}{*}{$\begin{array}{c}\text { Inhibition } \\
\text { of activity } \\
(\%)\end{array}$} & \multicolumn{2}{|c|}{$\begin{array}{l}\text { Reaction with cysteine } \\
\text { residues [mol DTNB } \\
\left.(\text { mol enzyme })^{-1}\right]\end{array}$} & \multirow[b]{2}{*}{$(\%)$} \\
\hline & & & - SDS & $+\operatorname{SDS}$ & \\
\hline WT & Tetramer & 15 & $4 \cdot 2$ & $27 \cdot 3$ & 15 \\
\hline MM6 & Tetramer & 16 & $4 \cdot 0$ & $26 \cdot 0$ & 15 \\
\hline MM8 & Tetramer & 18 & 3.9 & $30 \cdot 5$ & 13 \\
\hline \multirow{2}{*}{ MM 15} & Tetramer & 35 & $8 \cdot 5$ & $27 \cdot 3$ & 31 \\
\hline & $\begin{array}{l}\text { Monomer/ } \\
\text { dimer }\end{array}$ & ND & $25 \cdot 2$ & $26 \cdot 5$ & 95 \\
\hline
\end{tabular}

ND, Not determined (the monomer/dimer mixture did not exhibit amidase activity).

acetamide versus approximately $150 \%$ and $2 \%$ respectively).

Spectrophotometric analysis of the reaction between DTNB and the inactive form of the MM15 amidase (mainly monomers) indicated that essentially all of the cysteine residues were accessible to the inhibitor even in the absence of SDS. This suggested that the cysteines 
were located mainly on the interfacial surfaces of the subunits and were thus rendered largely inaccessible to DTNB when the enzymes were in their tetrameric forms. In spite of the apparent importance of cysteine residues for amidase activity, dithiothreitol ( $2 \mathrm{mM})$ did not protect either the wild-type or the MM15 enzyme against denaturation by heat or freezing and thawing.

\section{Physiological properties of strain MM15}

The above results suggested that the lower than expected amidase activity of strain MM 15 was caused by the high degree of dissociation of the enzyme in vivo into inactive monomers and dimers, and that this probably reflected the inherent thermolability of the enzyme. This hypothesis was tested by measuring the activity and concentration of the amidase following the growth of strain MM15 in continuous culture under acrylamide limitation at a series of different temperatures $\left(25-37^{\circ} \mathrm{C}\right.$; $D=0 \cdot 1 \mathrm{~h}^{-1}$ ) (Fig. 4). The results showed that cellular amidase activity was inversely related to the temperature of the culture, and that following growth at $25^{\circ} \mathrm{C}$ the activity was similar to that of strain MM8 grown at $37^{\circ} \mathrm{C}$ [i.e. 27.9 versus $24.4 \mu \mathrm{mol} \mathrm{min}^{-1}\left(\mathrm{mg}\right.$ cells) ${ }^{-1}$ measured with acetamide as substrate]. As the amidase concentration remained almost constant under all of these growth conditions $(22.4-24.3 \%$ of the cell protein), it was concluded that even at temperatures as low as the normal growth temperature $\left(37^{\circ} \mathrm{C}\right)$, the high thermolability of the enzyme has a strongly deleterious effect not only on the tetrameric structure of the MM15 amidase but also on its apparent $K_{\text {cat}}$.

\section{Purification and properties of amidase from strain MM15 grown at $25^{\circ} \mathrm{C}$}

The amidase was therefore purified from strain MM15 grown under acrylamide limitation at $25^{\circ} \mathrm{C}$ $\left(D=0 \cdot 1 \mathrm{~h}^{-1}\right)$ using the procedures described above for the purification of the wild-type and other mutant amidases. Pure amidase was obtained after a purification of only $4 \cdot 5$-fold, a value completely commensurate with the measured cellular amidase concentration $(22.4 \%$ of the cell protein) and which therefore indicated that all of the amidase was in the active, tetrameric form (compared with only approximately one-fifth following growth at $37^{\circ} \mathrm{C}$ ). The purified enzyme exhibited $K_{\text {cat }}$ values of $310 \mathrm{~s}^{-1}$ and $329 \mathrm{~s}^{-1}$, and $K_{\mathrm{m}}$ values of $1.2 \mathrm{~mm}$ and $2.5 \mathrm{~mm}$, for the hydrolysis of acetamide and acrylamide respectively, thus confirming its high $K_{\text {cat }} / K_{\mathrm{m}}$ ratio for acrylamide hydrolysis relative to that of the other enzymes. Gel-filtration FPLC and SDS-PAGE showed that the native and subunit $M_{\mathrm{r}}$ values (155000

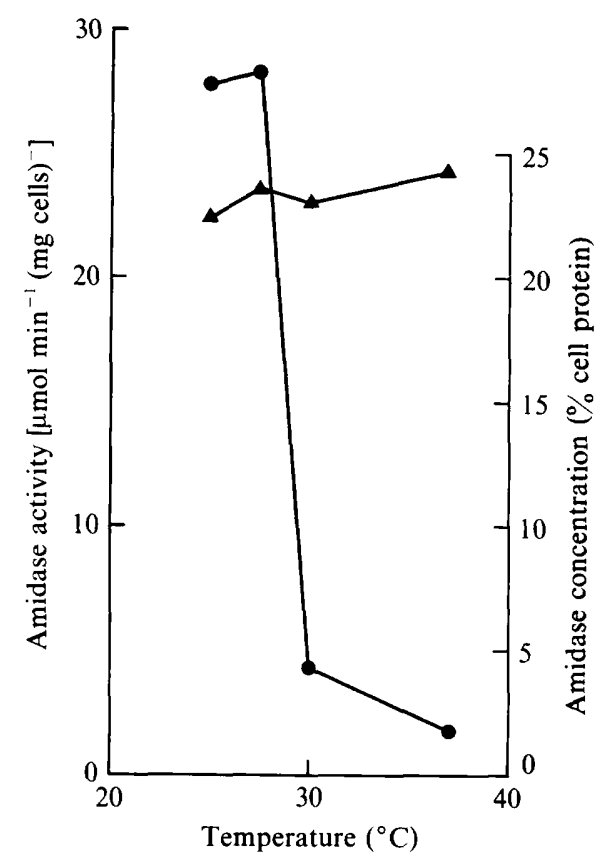

Fig. 4. Effect of growth conditions on the activity and concentration of amidase in $M$. methylotrophus strain MM15. The organism was grown in acrylamide-limited continuous culture $\left(D=0.1 \mathrm{~h}^{-1}\right)$ over the temperature range $25-37^{\circ} \mathrm{C}$. Amidase activity (O) was measured at $37^{\circ} \mathrm{C}$ with acetamide as substrate, and amidase concentration $(\boldsymbol{A})$ was determined by SDS-PAGE followed by scanning densitometry as described in Methods.

and 38000 respectively) were the same as those exhibited by the wild-type and other mutant amidases. Sedimentation-velocity ultracentrifugation revealed that the enzyme had a sedimentation coefficient of $6.78 \mathrm{~S}$, virtually identical to that of the wild-type, MM6 and MM8 enzymes. Reaction of the enzyme with DTNB also yielded similar results to those obtained with the wildtype, MM6 and MM8 enzymes, i.e. $18 \%$ inhibition of activity and a stoichiometry of $5.2 \mathrm{~mol}$ DTNB (mol enzyme $)^{-1}[28.5 \mathrm{~mol} \text { DTNB (mol enzyme })^{-1}$ in the presence of SDS]. All of these properties were commensurate with the amidase being a tightly associated tetramer. This was partly reflected in the substrate specificity of the enzyme, which was midway between that of the MM15 $\left(37^{\circ} \mathrm{C}\right)$ enzyme and the other enzymes [the rates of hydrolysis of propionamide and butyramide were $326 \%$ and $7 \%$ respectively of the rate with acetamide, versus $949 \%$ and $16 \%$ respectively for the $\operatorname{MM} 15\left(37{ }^{\circ} \mathrm{C}\right)$ enzyme, and $139 \%$ and $1.4 \%$ respectively for the wild-type, MM6 and MM8 enzymes].

\section{Discussion}

The isolation of mutant strains of bacteria using continuous culture is based upon selection for improved 
'biological fitness', i.e. the ability of the mutant to outgrow the original organism during growth under a particular nutrient limitation. Such mutants are altered in their ability to use the growth-limiting nutrient, normally as a result of changes in the activity or affinity of the first enzyme of the metabolic pathway that utilizes this nutrient (see Kubitschek, 1974; Harder et al., 1977; Mortlock, 1982; Dykhuizen \& Hartl, 1983; Hartley, 1984; Dykhuizen et al., 1987).

As small aliphatic amides probably enter cells rapidly by simple diffusion, amidase is the first enzyme of amide metabolism. Mutants which exhibit increased amidase activity at low amide concentrations are therefore potentially very susceptible to selection during growth at low dilution rate under amide limitation. We have recently used this type of approach with some success to isolate spontaneous mutants of $M$. methylotrophus which exhibit enhanced amidase activity as a result of synthesizing more of the wild-type enzyme (strain MM6) or more of an altered enzyme with a higher $K_{\text {cat }}$ (strain MM8) (Silman et al., 1989). The description in this paper of the subsequent isolation from a chemically mutagenized culture of strain MM8 of a mutant that synthesizes more of an altered enzyme with a lower $K_{\mathrm{m}}$ (strain MM15) thus confirms the selective advantage of such a phenotype. Furthermore, the ability of strain MM15 to synthesize more of an altered enzyme with both a high $K_{\text {cat }}$ and a low $K_{\mathrm{m}}$ during growth at $25^{\circ} \mathrm{C}$ rather than at the normal growth temperature of $37^{\circ} \mathrm{C}$ completes the four general types of amidase mutants that might be expected to be isolated using this type of 'directed evolution' approach, i.e. overexpression (MM6), overexpression plus a high $K_{\text {cat }}(\mathrm{MM} 8)$, overexpression plus a low $K_{\mathrm{m}}(\mathrm{MM} 15)$ and overexpression plus both a high $K_{\text {cat }}$ and a low $K_{\mathrm{m}}$ (MM15 grown at $25^{\circ} \mathrm{C}$ ).

As the Southern hybridization experiments showed no evidence of gene amplification in the mutant strains, it is likely that overexpression of amidase in these strains occurs via an up-promotor mutation (perhaps similar to that previously reported for the $P$. aeruginosa amidase as a result of selecting for altered substrate specificity; see Clarke, 1970, 1984; Clarke \& Drew, 1988), which is clearly retained during all stages of strain selection (MM6 $\rightarrow$ MM8 $\rightarrow$ MM15).

The necessity of having to use NTG mutagenesis to generate strain MM15 (in contrast to the spontaneous appearance of strains MM6 and MM8) suggests that the low- $K_{\mathrm{m}}$ phenotype may involve multiple and/or rare mutations in the amidase structural gene. It would also appear that the low- $K_{\mathrm{m}}$ phenotype is accompanied by increased thermolability, since the $K_{\mathrm{m}}$ for acrylamide and the $t_{1 / 2}\left(60^{\circ} \mathrm{C}\right)$ of the enzymes are both in the order wild-type/MM6 > MM8 $\gg$ MM15.

The wild-type amidase is similar to several other bacterial amidases (particularly the amidase from $P$. aeruginosa) in terms of its subunit $M_{\mathrm{r}}$ and/or N-terminal amino acid sequence, and in its sensitivity to inhibition by thiol reagents such as DTNB (which reacts with only one cysteine residue per subunit), but it differs in being a tetramer rather than a hexamer or an octamer (Clarke 1970, 1984; Asano, 1982; Thiery et al., 1986; Clarke \& Drew, 1988). Although the MM6, MM8 and MM15 enzymes are structurally similar to the wild-type enzyme, the MM15 enzyme is much more sensitive to inhibition by high temperatures or by freezing and thawing, and dissociates far more readily into inactive monomers and dimers, than any of the other enzymes. The greater propensity of the MM15 enzyme to undergo dissociation probably reflects its more open structure, as evidenced by its greater sensitivity to inhibition by DTNB (which reacts with eight cysteine residues per molecule; twice as many as in the wild-type, MM6 and MM8 enzymes, or in the MM15 enzyme synthesized during growth at $25^{\circ} \mathrm{C}$ ), by its lower sedimentation coefficient, and by its significantly enhanced relative activity with longerchain amides. It is possible, therefore, that the mutation(s) which gives rise to the low- $K_{\mathrm{m}}$ phenotype renders the enzyme more unstable, perhaps by altering the charge distribution on the interfacial surfaces of the subunits.

The later conclusion resolves the paradoxical observation that strain MM15 grown under acrylamide limitation $\left(D=0 \cdot 1 \mathrm{~h}^{-1}\right)$ exhibits an amidase activity which is only approximately one-fifteenth that of strain MM8 (in spite of containing approximately the same amount of enzyme), since the $K_{\text {cat }}$ is about two-thirds lower and approximately four-fifths of the enzyme is in the form of inactive monomers and dimers. As both of these properties are influenced by the temperature and retention time of the culture, it was concluded that the amidase activity of strain MM15 mainly reflects its very high thermolability, and this was confirmed by the observation that the amidase activity of strain MM15 grown at $25^{\circ} \mathrm{C}$ was similar to that of strain MM8 cultured at the normal growth temperature.

The remarkable feature of strain MM15 is that it outgrew strain MM8 at $37^{\circ} \mathrm{C}$ under acrylamide limitation in spite of having a much lower potential for acrylamide hydrolysis and of making up to approximately $18 \%$ of its cell protein as an inactive enzyme. It is clear, therefore, that a substantially increased affinity for the growth-limiting nutrient is an overwhelming selective advantage during growth at low dilution rates in continuous culture.

The authors are indebted to Professor W. J. Brammar for useful discussions, Dr A. J. Rowe for carrying out the analytical ultracentrifugation, Dr Kathryn Lilley for determining the $\mathrm{N}$-terminal amino acid sequence and John Keyte for synthesizing the oligonucleotides. The 
amino acid composition was determined by Dr L. Packman at the University of Cambridge. The work was supported through the award of an SERC CASE studentship (to N.J.S.) in collaboration with ICI Biological Products.

\section{References}

Ambler, R. P., Auffret, A. D. \& Clarke, P. H. (1987). The amino acid sequence of the aliphatic amidase from Pseudomonas aeruginosa. FEBS Letters 215, 285-290.

ANTHONY, C. (1982). The Biochemistry of Methylotrophs. London: Academic Press.

asano, Y., Tachibana, M., Tani, Y. \& Yamada, H. (1982). Purification and characterization of amidase which participates in nitrile degradation. Agricultural Biological Chemistry 46, 1175-1181.

Brammar, W. J., Charles, I. G., Matfield, M., Cheng-Pin, L., DREW, R. E. \& CLARKE, P. H. (1987). The nucleotide sequence of the amiE gene of Pseudomonas aeruginosa. FEBS Letters 215, 291-294.

CHOW, L. T., KaHMANN, R. \& KaMP, D. (1977). Electron microscopic characterization of DNAs of non-defective deletion mutants of bacteriophage Mu. Journal of Molecular Biology 113, 591-609.

Clarke, P. H. (1970). The aliphatic amidases of Pseudomonas aeruginosa. Advances in Microbial Physiology 4, 179-222.

Clarke, P. H. (1984). Amidases of Pseudomonas aeruginosa. In Microorganisms as Model Systems for Studying Evolution, pp. 187-231. Edited by R. P. Mortlock. New York: Plenum Press.

Clarke, P. H. \& DREW, R. (1988). An experiment in enzyme evolution. Studies with Pseudomonas aeruginosa amidase. Bioscience Reviews 8, 103-120.

Dykhuizen, D. E. \& HaRTL, D. L. (1983). Selection in chemostats. Microbiological Reviews 47, 150-168.

Dykhuizen, D. E., Dean, A. M. \& HarTL, D. L. (1987). Metabolic flux and fitness. Genetics 115, 25-31.

Hames, B. D. (1981). An introduction to polyacrylamide gel electrophoresis. In Gel Electrophoresis of Proteins; a Practical Approach, pp. 1-91. Edited by B. D. Hames \& D. Rickwood. Oxford: IRL Press.

Harder, W., Kuenen, J. G. \& Matin, A. (1977). Microbial selection in continuous culture. Journal of Applied Bacteriology 43, 1-24.
Hartley, B. S. (1984). Experimental evolution of ribitol dehydrogenase. In Microorganisms as Model Systems for Studying Evolution, pp. 23-54. Edited by R. P. Mortlock. New York: Plenum Press.

KUBITSCHEK, H. E. (1974). Operation of selection pressure on microbial populations. Symposia of the Society for General Microbiology 24, 105-130.

LARGE, P. J. \& BAmForth, C. W. (1988). Methylotrophy and Biotechnology. London: Longman.

Maestracci, M., Thiery, A., Bui, K., Arnaud, A. \& Galzy, P. (1984). Activity and regulation of an amidase (acylamide amidohydrolase EC 3.5.1.4) with a wide substrate spectrum from a Brevibacterium sp. Archives of Microbiology 138, 315-320.

Maestracci, M., Bui, K., Thiery, A., Arnaud, A. \& Galzy, P. (1988). The amidases from a Brevibacterium strain: study and applications. Advances in Biochemical Engineering/Biotechnology 36, 67-115.

Maniatis, T., Fritsch, E. F. \& Sambrook, J. (1982). Molecular Cloning: a Laboratory Manual. Cold Spring Harbor, NY: Cold Spring Harbor Laboratory.

MORTLOCK, R. P. (1982). Metabolic acquisitions through laboratory selection. Annual Review of Microbiology 36, 259-284.

Rowe, A. J. (1984). Techniques for determining molecular weight. In Techniques in the Life Sciences, vol, B1/1, suppl. BS106. Edited by K. F. Tipton, Amsterdam: Elsevier.

Silman, N. J., Carver, M. A. \& Jones, C. W. (1989). Physiology of amidase production by Methylophilus methylotrophus: isolation of hyperactive strains using continuous culture. Journal of General Microbiology 135, 3153-3164.

SpRAGG, S. P. (1980). The Physical Behaviour of Macromolecules with Biological Functions, pp. 66-68. Chichester \& New York: Wiley.

Thiery, A., Maestracci, M., Arnaud, A., Galzy, P. \& Nicolas, M. (1986). Purification and properties of an acylamide amidohydrolase (EC 3.5.1.4) with a wide variety spectrum from Brevibacterium sp. R312. Journal of Basic Microbiology 5, 299-311.

VASEY, R. B. \& Powell, K. A. (1984). Single-cell protein. Biotechnology and Genetic Engineering Reviews 2, 285-310.

Windass, J. D., Worsey, M. J., Pioli, E. M., Barth, P. T., Atherton, K. T., Dart, E. C., Byrom, D., Powell, K. \& Senior, P. J. (1980). Improved conversion of methanol to single cell protein by Methylophilus methylotrophus. Nature, London 287, 396-401.

Wyndham, R. C. \& Slater, H. J. (1986). A comparative study of acquired amidase activity in Pseudomonas sp. Journal of General Microbiology 132, 2195-2204. 